\title{
ECONOMIC BENEFITS FOR GREEN ROOFS: A CASE STUDY OF THE SKAGGS PHARMACY BUILDING, UNIVERSITY OF UTAH
}

\author{
T. WU \& R.E. SMITH \\ University of Utah, USA.
}

\begin{abstract}
This paper reports a return on investment (ROI) feasibility study of applying a green roof on a future pharmacy building at the University of Utah. A 40-year life cycle costs versus benefits comparative analysis has been performed for green roof, black roof, and reflective roof alternatives to quantify the economic benefits from green roofs. A green roof has a larger initial capital investment when compared with black or a reflective roof; however, the life cycle accumulative values of benefits from a green roof have been calculated at 27 years, positive net present value, and $100 \%$ ROI. This conclusion makes the green roof alternative a better advisable investment than the other two roof alternatives.
\end{abstract}

Keywords: energy efficiency, lifecycle cost, green roof benefits, return on investment.

\section{INTRODUCTION}

In August 2007, the University of Utah joined the Association for Advancement of Sustainability in Higher Education (AASHE), a national nonprofit group formed in 2005 as an information network and professional development resource for sustainability efforts on campuses across North America. To support the University's commitment to the AASHE vision and a sustainable future, a new Office of Sustainability (OS) was established within Facilities Management on July 1, 2007. The university has been actively working on a variety of sustainability initiatives, each overseen by their respective departments and working teams.

The OS supports graduate student projects that study the feasibility of green measures being implemented on existing and new campus facilities. This paper presents the work of a graduate internship in the OS and a qualifying project as part of a Masters of Science and Technology at the University of Utah. The main goal of the project was to perform a feasibility study to initiate a green roof on the new Skaggs Pharmacy Institute building that is in design (Fig. 1). This new building will be the new home for the College of Pharmacy, University of Utah, which is currently dispersed across six buildings throughout campus.

In addition to contributing to the OS university green building and sustainability planning initiatives on campus, this study is intended to provide qualifying data concerning the feasibility of green roofs for the Salt Lake community and larger intermountain region with similar climate. Due to the premature green roof market in North America, a typical initial investment for a green roof will be much higher than for a conventional roof. Without a life cycle cost and benefit analysis, building owners are reluctant to invest in the green roofs for retrofits and new construction. This study will help to establish an example of how to dress this costs versus benefits issue via life cycle system thinking, and to spur public recognition of green roofs benefits.

\section{BACKGROUND: BENEFITS OF GREEN ROOFS}

As the Bruntland Commission Report states, sustainability is a state of balance where the relationships between society, economy, and environment has to be maintained such that the needs of the present are met without compromising the ability of future generations of people and ecosystems to 


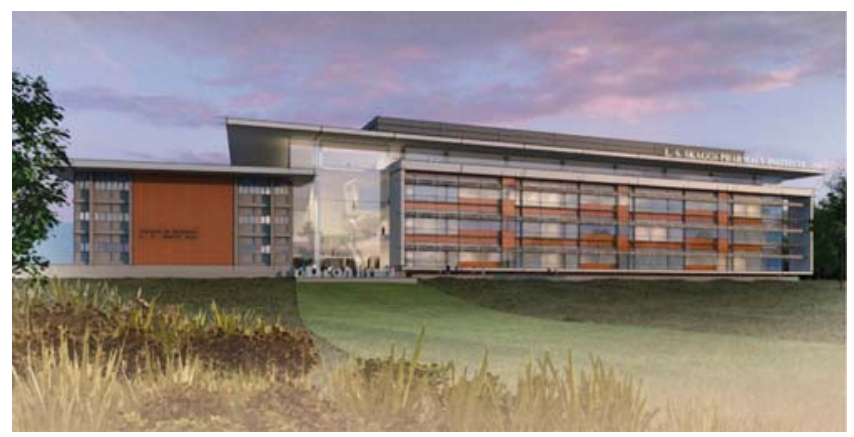

Figure 1: Architect's rendering of Skaggs Pharmacy Building, green roof feasibility case study.

meet their own needs [1]. As an option toward sustainability, benefits of green roofs can be understood from three aspects: economic benefits, environmental benefits, and social benefits.

Green roofs significantly moderate the daily temperature fluctuation experienced by roof membranes [2]. Economically, protection of roof membranes by green roofs results in a longer material lifespan and decreased maintenance and savings in replacement costs. Green roofs can reduce solar heat gain via direct shading of the roof, evaporative cooling from the plants and the growing medium, additional insulation values from both plants and growing medium, and thermal mass effects of growing medium. The ability of green roofs to insulate indoor environments can reduce power consumption for air-conditioning and save on energy costs. In addition, aesthetic appeal due to green roofs increases the value of the property and the marketability of the building as a whole. Green roofs are likely to be a positive selling point for developers in multifamily housing where taller commercial buildings have a view corridor toward the top of roofs and residents can physically access the green rooftop as an exterior shared space [3].

Green roofs reduce air pollution, as plants help remove carbon dioxide, carbon monoxide, nitrogen oxides, air-borne ammonia, sulfur dioxide and ozone, making the city a healthier environment for humans, plants and other animal life. Through the process of photosynthesis, plants convert carbon dioxide, water and sunlight/energy into oxygen and glucose. This cyclical process supplies animals and humans with oxygen and food. As such, green roofs provide an oasis in concrete deserts for wildlife habitat. In addition, conserving energy in buildings can reduce carbon dioxide $\left(\mathrm{CO}_{2}\right)$ and other harmful emissions from power plants. Green roofs can play a role in reducing the urban heat island (UHI) via the evapotranspiration process. With urban development, the rapid disappearance of open land has increased the amount of impervious surfaces, exacerbating runoff problems by reducing the amount of ground surface available to absorb water. When the same area, or large part of it is planted with a green roof, up to $90 \%$ of that storm water is captured, and the water that eventually runs off does so over periods of hours and days rather than minutes, allowing for gradual adsorption into the ground. Besides retaining water run off, green roofs can also play a critical role in purifying water and air by absorbing nitrogen and remediating the acidity and other contaminants of water running off of roofs.

Under the U.S. Green Building Council LEED program, which rates the environmental performance of buildings, green roofs gain one point for landscape to reduce heat island effects if the roof covers at least $50 \%$ of the building, and one point for storm-water management. As an added benefit, runoff from the green roof is filtered by the vegetation and soil media, so this water can be used to irrigate other landscaping features without pretreatment. In LEED, this may warrant an additional point for water efficient landscaping. The ability to reduce energy demand for cooling and increase 
energy efficiency may also garner additional points for optimized energy performance. In addition, potential points can be gained for reduced site disturbance, protection or restoration of open space, and innovation in design [4].

Green roofs provide social benefits as well including sound insulation and aesthetic contributions. Roof spaces have large potential in providing urban dwellers with the amenity and recreational space essential for healthy living. Green roofs promote sustainability recognition with an educational value to the community. Green roofs are a relatively new idea in the U.S., and developers and building owners normally hesitate to install them due to higher initial installation costs, lack of knowledge, little technical support, and few precedents. More importantly, green roofs are overlooked because the benefits are not systematically quantified. Therefore, building owners have difficulty evaluate green roofs' value that is critical to making decisions regarding lifecycle cost. This paper will provide a methodology and feasibility for green roof Return on Investment (ROI) in comparison to conventional roofing on the Skaggs Pharmacy Institute at the University of Utah in Salt Lake City.

\section{METHODOLOGY STEP 1: BENEFITS AND MONETARY VALUES}

Based on a literature review, the quantifiable benefits of green roofs were calculated and applied to the new Skaggs Pharmacy Institute building. Once the impacts were quantified in terms of their respective benefits, corresponding monetary values were developed for each of the benefits.

\subsection{Energy saving for cooling}

The savings in energy resulting from a green roof are considerable. Green roofs reduce heat gain through shading, insulation, evapotranspiration and thermal mass, and reduce heat loss only through insulation and decreased radiation heat losses. However, green roofs can also be as effective at preventing heat loss in the winter. However, in this scenario, the green roof must be specifically designed for winter use including deeper soil and larger winter plants to increase insulation. In this study, it is assumed that the Pharmacy Institute building will invest in an extensive green roof, reducing the depth of soil thus resulting in energy savings mostly in cooling, but not in heating. For the purposes of this study, energy savings due to heating reductions are negated.

The percentage of reduction in cooling energy costs can be difficult to estimate due to dependence on a confluence of factors such as design, layout, and functional use of the building. In addition, physical factors such as envelope insulation and the size and design of the green roof itself including soil thickness, density, and moisture content, etc. For the purpose of this study, green roof detailed specifications have not been chosen, and it is assumed that different combinations of characteristics will result in different energy savings. Therefore, estimates for energy reduction percentages used in this study have been assumed based on historical precedents. The following energy percent reduction estimates have been found:

1. Simulation studies on the green roofs atop Chicago's big buildings reveal that structures can expect a $10 \%$ reduction in air-conditioning needs during the cooling season. In other studies, researchers have found that green roofs on smaller buildings can reduce solar heat gain by as much as $95 \%$ and reduce cooling needs from 25 to $50 \%$ [5].

2. In 2008, the Greek Ministry of Finance installed a green roof on the Treasury building in Constitution Square in Athens [6]. The 10-floor building has a total floor space of 150,694 square feet (s.f.), and a green roof area of $650 \mathrm{~m}^{2}$ (6,994 s.f.), equaling $52 \%$, or over half of the roof space. One year after installation, research was conducted by the School of Mechanical 
Engineering, National Technical University of Athens. According to the measurements of research the temperature difference arising between the planted and non-planted area of housing reaches $18^{\circ} \mathrm{C}$. At the same time, energy savings of 50\% were observed for air conditioning in the floor directly below the installation, and $9 \%$ saving in air conditioning for the whole building on an annual basis [7].

3. On a one-story building green roof experimental test bed in Ottawa, Canada, with an 800 s.f. roof was divided into two equal areas separated by a median parapet with a generic extensive rooftop garden installed on one side and a conventional roofing assembly installed as a reference on the other. It was found that a 6-inch extensive green roof reduced heat gains by $95 \%$ and heat losses by $26 \%$ compared to the reference roof. When the outdoor temperature peaked at $35^{\circ} \mathrm{C}(95 \mathrm{~F})$ in the summer, the membrane on the reference roof absorbed solar radiation and reached $\sim 70^{\circ} \mathrm{C}(158 \mathrm{~F})$, while the membrane on the rooftop garden remained at $25^{\circ} \mathrm{C}(77 \mathrm{~F})$. Heat flow through the building envelope creates energy demand for space conditioning in a building. The average daily energy demand in summer for space conditioning in the case of the reference roof was $6.0-7.5 \mathrm{kWh}(20,500-25,600 \mathrm{BTU})$. However, the growing medium and the plants modified the heat flow and reduced the average daily energy demand to less than $1.5 \mathrm{kWh}$ (5,100 BTU) - a reduction of more than 78\% [8].

4. A monitored study by Florida Solar Energy Center evaluated summer energy performance aspects of a green roof on a two-story central Florida university building addition that was completed in 2005. One half of the two-story project building's 3,300 s.f. roof is a light-colored, conventional flat membrane roof, the other half being the same membrane roof covered with 6-8 inch of soil and plant media and $\sim 2$ feet of soil and a variety of primarily native Florida vegetation. Both sides of the roof were monitored for average heat flux rates, and the energy consumption due to cooling loads was calculated and compared. It was assumed that an airconditioning $(\mathrm{A} / \mathrm{C})$ system efficiency of $10 \mathrm{Btu} / \mathrm{h} \times \mathrm{W}$ (including fan power and distribution losses), and that all heat gain through the roof was removed by the $\mathrm{A} / \mathrm{C}$ system alone. Compared with the conventional roof, the green roof saved $18 \%$ of energy for cooling in the summer of 2005 , and 44\% when the plant more established in summer of 2006 [9].

5. A DOE-2 simulation study of a green roof on a five-story Singapore commercial building with 10,394 s.f. rooftop area showed annual energy consumption savings of $1 \%$ to $15 \%$, and $17 \%$ to $79 \%$ of energy saving for space cooling. The saving depends on characteristics of the green roof, such as the type of plants and thickness of soil. According to their simulation, the optimum type of green roof plants is shrubs. A green roof with $300 \mathrm{~mm}(\sim 12$ inch) thick soil and shrubs could achieve a saving of $15 \%$ in the annual energy consumption, and $79 \%$ in the space-cooling requirement [10].

As described above, 6,994 s.f. green roof on the Treasury in Constitution Square in Athens is able to save $50 \%$ energy for cooling in the top floor one year after initial installation. The Athens building $(150,694$ s.f.) has very similar gross floor area to the Pharmacy Institute building (150,000 s.f.) with the difference being the ratios of building envelope's roof area to interior volume. The Pharmacy Institute building will be five stories including parking level. Compared to the Athens building, the Pharmacy Institute building will have about two times rooftop area, half of the building height (levels), and more than two times the area to volume (A/V) ratio. General speaking, with similar building insulation, building with higher $\mathrm{A} / \mathrm{V}$ ratio tend to be more energy efficient. Balancing all factors as well as the fact that summer in Athens is even hotter and drier than Salt Lake City [11], it's not unreasonable to conservatively estimate that the 50\% coverage green roof on Pharmacy Institute building would be able to save $35 \%$ energy for cooling in the top floor in the first two years 
after initial installation, and $40 \%$ saving for cooling is expected starting from the 3rd year, when all plants are fully established.

To estimate the energy saving for cooling in the five-floor building, a simple simulation has been established based on the case of the Athens building that energy savings of 50\% for $\mathrm{A} / \mathrm{C}$ cooling in the top floor below the roof, and $9 \%$ saving in cooling loads for the whole building. This simulation is performed under two assumptions: (1) the saving percentage is exponentially decaying from top to ground level; (2) for simplicity, the energy consumption for cooling at each floor is averaged as $1 / 10$ of the total energy consumption for cooling the whole building. Using the same decay parameter, the energy saving for cooling in the five-floor building can be simulated and estimated as $12.4 \%$ in the first 2 years, and $14.2 \%$ thereafter.

According to College of Pharmacy, University of Utah, the new Skaggs Pharmacy Institute building will be five stories including a parking level, with a total of 150,000 s.f. gross floor area. The power requirement and functional pattern will be very similar to the Biomedical Polymer Research Building (BPRB), another laboratory building on campus. Therefore, the electricity consumption by the BPRB was used as a reference to calculate the power requirement for the future Pharmacy Institute building.

The electricity consumption by BPRB is monitored and recorded by the Department of Energy Management at the University of Utah. Based on their data on the annual energy expenditure of the BPRB, for the gross building area of 130,159 s.f., an average annual electricity consumption from 2004 to 2008 is $4,355,540 \mathrm{kWh}$ [12]. The electricity consumption for unit area is $33.46 \mathrm{kWh} / \mathrm{s} . f$. Therefore for the Pharmacy Institute building with 150,000 s.f., the annual electricity consumption can be proportionally estimated at 5,019,484 kWh. As described above, since the Pharmacy Institute building will likely invest in an extensive green roof, the savings in energy resulting from a green roof will be evaluated in cooling costs.

When compared with the Commercial Building Energy Consumption Survey (CBECS) database, electricity consumption per unit area in BPRB (33.46 kWh/s.f.) is much higher than the statistical value for office buildings with 100,000-200,000 s.f. floor area (15.7 kWh/s.f.) [13]. Such a discrepancy is mostly likely due to the fact that the BPRB houses laboratory functions and not office facilities alone. To estimate the energy due to cooling in the Pharmacy Institute building, instead of merely referring the CBECS database, an assumption is made to consider the difference between summer electrical peaks and fall through spring usage due to extra need of cooling in summer. Under this assumption, the energy consumption for cooling during the summer months can be calculated based on the annual energy expenditure of the BPRB recorded by Facility Management. For the $\mathrm{BPRB}$, an average of $566,486 \mathrm{kWh}$ of extra electricity is the consumed in comparison to CBECS values during May to September, accounting for about $13 \%$ of the annual total electricity consumption. Proportionally the annual electricity for cooling in the future Pharmacy Institute building can be estimated as $652,839 \mathrm{kWh}$. If the new building's roof is half greened, $12.4 \%$ of electricity will be saved for cooling in the first 2 years, and $14.2 \%$ thereafter, i.e. $80,952 \mathrm{kWh}$ per year in the first 2 years, and 92,703 kWh per year thereafter.

Based on the official energy statistics by Energy Information Administration, the average retail price of electricity to ultimate customers in commercial sectors in Utah was $6.63 \mathrm{c} / \mathrm{kWh}$ in 2008 and $6.91 \mathrm{c} / \mathrm{kWh}$ in 2009 ( 4\% annual increase) [14]. Noted are the highest cost months of $7.52 \mathrm{c} / \mathrm{kWh}$ in June 2008 and $7.91 \mathrm{c} / \mathrm{kWh}$ in June 2009 ( 5\% summer increase). University of Utah is one of the main customers of Rocky Mountain Power, according to Chris Kanoff, the project manager from Rocky Mountain Power [15]. University of Utah is on Schedule 9 in their category pricing power at $5.5 \mathrm{c} / \mathrm{kWh}$. According to Kanoff, historical values suggest it is reasonable to assume a $5 \%$ rate increase per year after 2010, especially for summer. Prices offered by Rocky Mountain Power to 
University of Utah has been $30 \%$ lower than the state average, which is already much lower than the national average. Trends in the 2 years indicate higher prices (average $5.1 \mathrm{c} / \mathrm{kWh}$ ) charged from May to October than off peak season (average $4.4 \mathrm{c} / \mathrm{kWh}$ ). In this study, since most energy saving will be realized from cooling in peak season, $5.1 \mathrm{c} / \mathrm{kWh}$ will be applied as an initial price, and $5 \%$ rate increase per year is assumed in the analysis.

\subsection{Reduction of emission from power generation}

The primary harmful emissions from electricity power generation include carbon dioxide $\left(\mathrm{CO}_{2}\right)$, methane $\left(\mathrm{CH}_{4}\right)$, nitrous oxide $\left(\mathrm{N}_{2} \mathrm{O}\right)$, nitrogen dioxide $\left(\mathrm{NO}_{2}\right)$, sulfur dioxide $\left(\mathrm{SO}_{2}\right)$, small particulate matter $\left(\mathrm{PM}_{10}\right)$, and volatile organic compounds (VOC). The first three in the list are counted as Greenhouse Gases, contributing to the Greenhouse Effects and global climate change. The other emissions are not greenhouse gas, but do contribute to the degradation of air quality. Conserving energy in buildings can reduce greenhouse gas $\left(\mathrm{CO}_{2 \mathrm{eq}}\right)$ and other harmful emissions from power plants. Emission reductions can be calculated as the product of energy savings from cooling load reductions associated with emission factors.

After University of Utah President Michael K. Young joined more than 500 other college and university presidents in signing the American College and University Presidents Climate Commitment (PCC), the University of Utah Office of Sustainability has accomplished a Green house Gas (GHG) Inventory. OS based their calculations in the inventory on the eGRID NWPP (Northwest) region database by U.S. Environmental Protection Agency [16]. As results, in University of Utah, total carbon emission factor $\left(\mathrm{CO}_{2 \mathrm{eq}}\right)$ from electricity is $422 \mathrm{~g} / \mathrm{kWh}(0.93 \mathrm{lbs} / \mathrm{kWh})$, including $418 \mathrm{~g} / \mathrm{kWh}$ for $\mathrm{CO}_{2}, 0.006 \mathrm{~g} / \mathrm{kWh}$ for $\mathrm{CH}_{4}$, and $0.014 \mathrm{~g} / \mathrm{kWh}$ for $\mathrm{N}_{2} \mathrm{O}$, respectively. Factors for other emissions are proportionally calculated, comparing the emission factor for $\mathrm{CO}_{2 \mathrm{ec}}$ in NWPP region to that of the whole nation, from the data presented in a general technical report prepared by U.S. Department of Agriculture (USDA) Forest Service, Pacific Southwest Station in 2007 [17]. This data rates factors for other emissions from electricity power generation at $0.82 \mathrm{~g} / \mathrm{kWh}(1.80 \mathrm{E}-03 \mathrm{lbs} / \mathrm{kWh})$ for $\mathrm{NO}_{2}, 0.56 \mathrm{~g} / \mathrm{kWh}(1.23 \mathrm{E}-03 \mathrm{lbs} / \mathrm{kWh})$ for $\mathrm{SO}_{2}, 0.28 \mathrm{~g} / \mathrm{kWh}$ $(6.24 \mathrm{E}-04 \mathrm{lbs} / \mathrm{kWh})$ for $\mathrm{PM}_{10}$, and $0.26 \mathrm{~g} / \mathrm{kWh}(5.74 \mathrm{E}-04 \mathrm{lbs} / \mathrm{kWh})$ for $\mathrm{VOC}$, respectively. Based on these factors, the emission reduction can be calculated for specific electricity savings described in the previous subsectionThe values of reduced emissions, either internalized or externalized in the energy pricing or regulatory policies system, should be counted as a result of reduced electricity consumption. In the USDA Forest Service report mentioned above, the values of reduced emissions are estimated as following: $\$ 3.34 \mathrm{E}-03 / \mathrm{lb}$ for $\mathrm{CO}_{2 \mathrm{eq}}, \$ 0.51 / \mathrm{lb}$ for $\mathrm{NO}_{2}$, $\$ 0.06 / \mathrm{lb}$ for $\mathrm{SO}_{2}, \$ 0.92 / \mathrm{lb}$ for $\mathrm{MP}_{10}$, and $\$ 0.14 / \mathrm{lb}$ for VOC. Therefore there should be saving of $\$ 3.1 \mathrm{E}-03 / \mathrm{kWh}$ for $\mathrm{CO}_{2 \mathrm{eq}}, \$ 9.2 \mathrm{E}-04 / \mathrm{kWh}$ for $\mathrm{NO}_{2}, \$ 6.6 \mathrm{E}-04 / \mathrm{kWh}$ for $\mathrm{SO}_{2}, \$ 6.1 \mathrm{E}-04 / \mathrm{kWh}$ for $\mathrm{PM}_{10}$, and $\$ 7.7 \mathrm{E}-05 / \mathrm{kWh}$ for VOC.

Therefore, if the Pharmacy Institute building's roof is half greened, 80,952 $\mathrm{kWh}$ per year will be saved in the first 2 years, and $92,703 \mathrm{kWh}$ per year thereafter. In addition to energy saving for cooling an annual monetary benefit for the green roof due to reduced emissions will be estimated at $\$ 385 /$ year in the first 2 years, and $\$ 441 /$ year thereafter.

\subsection{Storm water runoff management}

The storm water retaining behavior of green roofs depend on climatic conditions such as volume, intensity and frequency of rainfall, drying rates, and the depth and saturation level of the existing substrate. Many studies have been performed, as summarized below, to quantify the benefits green 
roofs can offer for storm water runoff management. It is difficult to generalize results of research studies, particularly if they were conducted in a different climate zone.

1. Within a 15-month monitoring period, research in City of Portland by Liptan et al. demonstrated that precipitation retention by an extensive green roof with 4 inch deep substrate was $\sim 69 \%$ of the total rainfall [18]. It was also indicated that there were noticeable differences between retention in warm weather and in cool weather. Between December and March the rainfall retention was 59\%, while from April to November, rainfall retention was $92 \%$.

2. A North Carolina field study by Moran et al. found that monthly storm water retention rates varied between $40 \%$ and $100 \%$ on two green roofs in the Neuse River watershed [19].

3. A replicated study in Austin, TX, by Simoons et al. compared the performance of six different extensive green roof designs vegetated with 4 inch growth medium and identical native species [20]. Their results indicated maximum run-off retention between $88 \%$ and $44 \%$ for medium and large rain events.

4. A storm water model was built by Limno-Tech to quantify the cumulative contribution green roofs make toward reducing storm water runoff and combined sewer overflow events in the District of Columbia. In this model, it was predicted that an extensive green roof could reduce roof runoff volumes by $\sim 65 \%$, while an intensive roof can reduce runoff by $85 \%$. Using a combination of $80 \%$ extensive and $20 \%$ intensive ratio across all green roof-ready buildings in the District, roof runoff volume would decrease by as much as $69 \%$ when compared to conventional rooftops.

Salt Lake City average annual rainfall is about 16.5 inch, and annual snowfall at the airport averages 58.7 inch, totaling 22.4 inch equivalent rainfall per annum [21]. As a comparison, precipitation (rainfall plus snowfall) totals 36.3 inch for Portland, 56 inch for North Carolina, 32 inch for Austin, and 41 inch for DC. Technical data from Hydrotech ${ }^{\circledR}$ Garden Roof Assembly claims that the combination of the soil and Hydrotech ${ }^{\circledR}$ Garden Roof components can retain between $50 \%$ and $90 \%$ of a typical rain that falls on the roof surface [22]. Based on a hydrology computation developed by licensed professional civil engineers exclusively for Hydrotech ${ }^{\circledR}$, a Hydrotech ${ }^{\circledR}$ green roof with 12 inch deep growing media and sedum/succulents is able to retain annually $90 \%$ of storm water runoff in Salt Lake City [23].

According to the Salt Lake City Storm Water Ordinance, there are imposed storm sewer service fee rates and charges on each parcel of property within the city, except government owned streets and storm water facilities operated and maintained by, or for, the county [24]. The charges fund the administration, planning, design, construction, water quality programming, operation, maintenance and repair of existing and future storm water facilities. In Salt Lake City, the normal annual precipitation (rainfall and snowfall counted, see section 4 for the conversion) is around 22.4 inch, i.e. 1.87 cubic feet or 13.96 gallons per s.f. The charge for all parcels other than residential and undeveloped parcels is based upon the total square feet of measured impervious surface divided by 2,500 s.f. or one Equivalent Residential Unit (ERU), and rounded to the nearest whole number. The actual total monthly service charge shall be computed by multiplying the total ERUs for a parcel by the monthly rate of $\$ 3$. Therefore the storm sewer service fee would be $\$ 0.072 /$ s.f./year, or $\$ 0.005 / \mathrm{G} /$ year in Salt Lake City. The price is consistent with the database from USDA Center for Urban Forest Research, where retention/detention of storm water runoff costs are \$0.005/G/year, covering administrative, sewer collection, and treatment costs [25].

Based on this estimation, in the case of Pharmacy Institute building, runoff from its 30,000 s.f. roof can be estimated as $418,800 \mathrm{G} / y e a r$, and the annual cost of retention/detention will be $\$ 2,094$. 
If half of the roof is covered by green roof, runoff in the greened half will be reduced by $90 \%$, leading to retention of $188,460 \mathrm{G} /$ year, or $\$ 942 /$ year.

\subsection{Air quality improvement}

Green roofs are expected to have positive benefits for air quality improvement via adsorption. Airborne particulate, nitrogen oxide, ozone, sulfur dioxide, and carbon monoxide levels have been assumed to decrease in the presence of green roofs. The air quality improvement is hard to quantify but several studies and results are summarized herein.

1. The level of air pollution removal by green roofs in Chicago was quantified using a dry deposition model based on a detailed survey of 71 green roofs. The results showed that a total of $1675 \mathrm{~kg}$ of air pollutants was removed by 19.8 Hectare (ha) of green roofs in 1 year with $\mathrm{O}_{3}$ accounting for $52 \%$ of the total, $\mathrm{NO}_{2}(27 \%), \mathrm{PM}_{10}(14 \%)$, and $\mathrm{SO}_{2}(7 \%)$. The highest level of air pollution removal occurred in May and the lowest in February. The annual removal per ha of green roof was $85 \mathrm{~kg} / \mathrm{ha} /$ year [26].

2. The reduction of air pollutants by green roofs in Toronto was simulated with the Urban Forest Effects (UFORE) model D, which was developed by the USDA Forest Service Northeastern Regional Station. Pollution removal was calculated for $\mathrm{O}_{3}, \mathrm{SO}_{2}, \mathrm{NO}_{\mathrm{x}}, \mathrm{CO}$ and PM10. The results indicated that about 109 ha of green roofs in Toronto could remove a total of 7.87 metric tons of air pollutants annually [27].

3. The same UFORE model was used to simulate the benefits of air pollution reduction from green roofs in Washington DC. In this model, a 50-50 grass/evergreen shrub mix was used to approximate the average composition of green roofs. The results indicated that $\sim 16.8$ metric tons of air pollutants could be removed by 21.7 million s.f. of green roofs in Washington DC per year, with $\mathrm{O}_{3}$ accounting for $35 \%$ of the total, $\mathrm{NO}_{2}(13 \%), \mathrm{PM}_{10}(34 \%), \mathrm{CO}(13 \%)$, and $\mathrm{SO}_{2}(5 \%)$ [28].

All of the three studies showed similar results of total air pollutants removal by green roofs at $0.078 \mathrm{metric}$ tons/ha/year, or $0.0016 \mathrm{lb} / \mathrm{s} . \mathrm{f}$./year. The fractions of each pollutant removal vary between the Chicago and Washington DC model, but the sums of removal are nearly consistent.

According to a study by USDA Forest Service, air pollutants removal can be converted to monetary values, which were estimated in this study using the median externality values for United States for each pollutant [29]. The unit monetary values for pollutant removal are: $\mathrm{O}_{3} \$ 3.06 / \mathrm{lb}, \mathrm{PM}_{10}$ $\$ 2.05 / \mathrm{lb}, \mathrm{NO}_{2} \$ 3.06 / \mathrm{lb}, \mathrm{SO}_{2} \$ 0.75 / \mathrm{lb}, \mathrm{CO} \$ 0.43 / \mathrm{lb}$, and total pollutants $\$ 2.38 / \mathrm{lb}$, multiplied by the total air pollutants removal by green roofs, i.e. about $0.0016 \mathrm{lb} / \mathrm{s}$.f./year, the monetary value for air pollutant removal will be $\$ 0.004 /$ s.f./year.

In the case of Pharmacy Institute building, if a green roof is installed with 50\% coverage of the rooftop, the total air pollutant removal will be expected at $24 \mathrm{lb} / \mathrm{year}$, leading to a monetary benefit of about $\$ 60 /$ year.

\subsection{Roof lifespan extension and maintenance saving}

European research suggests that protection of roofing membranes results in a longer material lifespan and decreased maintenance and savings in replacement costs. Typically a traditional built-up roof is considered to have a minimum 20-year life expectancy, and many built-up flat roofs last 30 years. Normally the roofing contractor offer a warranty for primary repairs during the first 20 years, and in the end of 30 years a replacement may be needed to achieve optimum function of the roof. On large 
buildings, single-ply systems are becoming more common with an expected span of 15-20 years [30]. Within the lifespan of 35-40 years for a green roof, at least one tear-up and replacement not covered by the contractor warranty will be needed for a conventional roof. However, the replacement cost for a conventional roof can be saved by a green roof alternative.

Typical price for conventional roof installation and 20-year warranty is estimated as $\$ 7$ per s.f. According to a roofing price calculator designed by IB Roof Systems, around $20 \%$ more will be charged for existing roof tear up and roof replacement [31]. Therefore, the replacement cost would be around $\$ 8.4$ per s.f. for a conventional roof assumed to take place at the 30 year mark.

\subsection{Evaluation of benefits from reflective roofs}

Green roofs are not the only roofing solution to reduce heat transfer into a building and realize energy savings in cooling load reduction. Highly reflective roofs, or white roofs, also achieve thus function, but they lack many of the other advantages of green roofs, such as storm water retention, adsorption of air pollutants, migration of UHI effect, and so on. Light colored, reflective roofing typically saves energy on cooling through reflecting solar radiation. Its performance has been summarized below based on literature review:

1. In a 2001 building field study of a one-story retail store, with 100,000 s.f. roof top area, in Austin, TX, Lawrence Berkeley National Laboratory (LBNL) identifies a reduction of the average summertime daily maximum roof-surface temperature from $168^{\circ} \mathrm{F}\left(76^{\circ} \mathrm{C}\right)$ to $126^{\circ} \mathrm{F}\left(52^{\circ} \mathrm{C}\right)$ by applying a reflective roof membrane. The total air-conditioning energy consumption was reduced by $11 \%$ and peak air-conditioning demand fell by $14 \%$ [32].

2. In a 2002 Department of Energy (DOE) simulation study of five cities (Baton Rouge, LA; Sacramento, CA; Salt Lake City, UT; Chicago, IL; Houston, TX), Konopacki and Akbari at LBNL identified an average 3.94\% savings on building cooling energy consumption by applying high-albedo roof material to office buildings metropolitan-wide [33].

In the case of the University of Utah Pharmacy Institute building, a reflective roof installation is assumed to yield an $11 \%$ energy saving for cooling the floor directly below the roof based on the Austin, Texas study. However, it is also reasonable to expect decay of the saving percentage from 5th to 1st level. Due to such decay, it is estimated that the energy saving for cooling the whole Pharmacy Institute building is $6 \%$.

\section{METHODOLOGY STEP 1: CAPITAL INVESTMENT EVALUATION}

The cost of a green roof and its installation will vary greatly based on the design. An exemplarily system in the industry, Hydrotech ${ }^{\circledR}$ offers a complete green roof system covered from deck up to plants, offering specific details based on soil and plants appropriate for Salt Lake regional climate. The company hosts authorized green roof installers local in Utah, both install and maintenance. In Salt Lake City, the well-known and award winning green roof on the LDS Conference Center uses the Garden Roof Assembly system supplied by Hydrotech ${ }^{\circledR}$ (Fig. 2). It is not unreasonable to assume

that the Pharmacy Institute in University of Utah would install a Hydrotech ${ }^{\circledR}$ green roof, or one that is similar in price and quality. Thus, to simplify the study, the capital investment estimate herein is based on Hydrotech ${ }^{\circledR}$ Garden Roof Assembly price.

Based on precedent pricing, a green roof by Hydrotech ${ }^{\circledR}$ for an extensive green roof system with 12 inch soil depth at the Pharmacy Institute project would be \$18-\$22 per s.f. This price is subject to the following variables: the extent and types of curbs and pavers, and the overall size and shape 


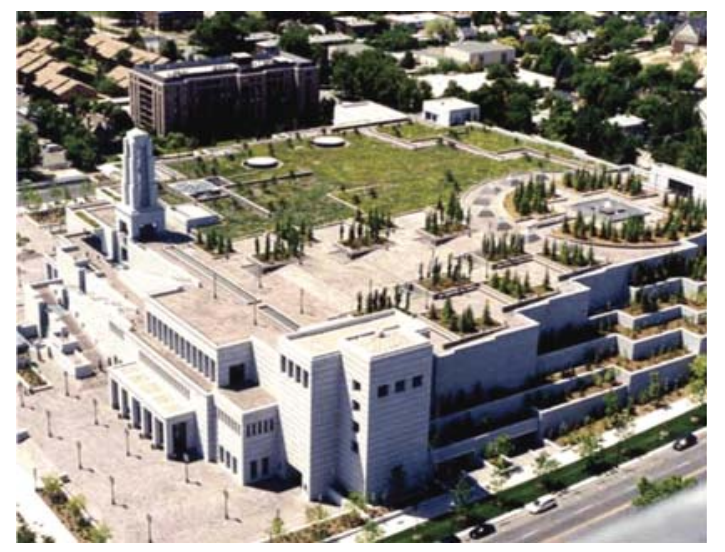

Figure 2: LDS Conference Center in downtown Salt Lake City is host to a Hydrotech intensive green roof system.

of the proposed vegetated roof area. It should be noted that less complex or larger scale projects are more affordable per s.f. For instance, the cost for an installed green roof system with materials and labor for a 100,000 s.f. can be well under $\$ 20$ per s.f. Lower costs may also be achieved using a paver systems that is installed outside of the vegetated zones and utilized a cast in place curbing instead of pre-cast curbing.

After installation, the health and longevity of a green roof will ultimately depend on regularly scheduled and proper maintenance over time. Regular inspection, trimming, and weeding will be needed in order to ensure longevity and performance. For any kind of green roof, initial watering and occasional fertilization are required until the plants have fully established themselves. This process normally takes 2 years. For the Hydrotech ${ }^{\circledR}$ Garden Roof Assembly system, a quote of \$18-\$22 per s.f. includes maintenance for the first 2 years, with a Thrive Warranty that guarantees $50 \%$ plant growth in year one and $80 \%$ by year two. Once the selected plants are healthy and well established, extensive green roofs no longer need to be irrigated except in cases of extreme drought. Regular fertilization with a slow release fertilizer twice a year will prevent acidification of the thin soil layer. After the first 2 years, it is optional to extend the maintenance contract by Hydrotech ${ }^{\circledR}$ authorized contractor. According to Hydrotech ${ }^{\circledR}$, the green roof can also be maintained by personnel from Landscape Maintenance \& Transportation in the university, who have gained green roof maintenance experience from two other existing green roofs on University of Utah campus. In order to be conservative in the economic study for the Pharmacy Institute building green roof in this study, it is assumed that no extended maintenance will be secured from the contractors, and university personnel will maintain the green roof long term beyond the 2-year initial period.

Under the U.S. Green Building Council LEED program which rates the environmental performance of buildings, green roofs gain one point for landscape to reduce heat island effects if the roof covers at least $50 \%$ of the building, and one point for storm-water management. As the University of Utah is aggressively seeking LEED certification on its new construction projects, this financial analysis will assume $50 \%$ of green roof coverage, and the Hydrotech ${ }^{\circledR}$ system installation price will be estimated as $\$ 20$ per s.f. The roof area for the Pharmacy Institute building is designed at 30,000 s.f. The green roof capital investment, including materials, installation, and 2-year maintenance and warranty, is estimated at $\$ 300,000$. The lifespan of the green roof is expected to be 40 years. 


\section{FINANCIAL ANALYSIS FINDINGS}

In the life cycle financial analysis, the service life for a green roof is assumed at 40 years, while a conventional roof is rated for 30 years. To simplify the complexity of accounting for inflation within the present value equation, real discount rate is used in this life cycle study, which is $2.8 \%$ based on the economic assumptions from the 2009 Budget [34].

In this financial case study, the total cost is the initial investment for installation and maintenance, and the total sales are the cumulative monetary benefits resulting from the green roof. The breakeven point for this project is approximately 27 years. The net present value (NPV) calculation provides the value in today's dollars for the stream of 40 years of financial benefits discounted by the $2.8 \%$ real interest rate. The NPV value for the financial case study is found to be $\$ 38,926$. Since this is a positive amount, investing in this green roof is advisable. Return on investment, ROI, is the primary measure of profitability for investors. The net income in this financial case study is the sum of the yearly monetary benefits. The investment is the initial capital required for green roof materials, installation, and maintenance. The ROI has been calculated to be $100 \%$, indicating that the green roof will be profitable. The calculations for this financial case study can be found in Table 1 .

As an alternative option, a similar methodology has been used to estimate ROI for a reflective roof, shown in Appendix A as well. For a reflective roof, the breakeven point is $\sim 38$ years; ROI is $100 \%$ within the life cycle of 40 years. The NPV value is found to be $-\$ 25,620$. Comparing a reflective roof with a conventional black roof, which has non-applicable ROI and -\$155,668 NPV value, the reflective roof is a much better alternative. However, since NPV for a reflective roof alternative is a negative amount, investing in a reflective roof is less advisable than a green roof alternative as illustrated in Table 1 and 2.

\section{CONCLUSIONS}

In this work, the quantifiable benefits of a green roof have been calculated and transferred into monetary values. Based on the feasibility study, the benefits of a green roof make itself an advisable investment for the Skaggs Pharmacy Institute. Outside of sound financial sense, a green roof would benefit UHI effect migration, contribution to community urban living, preservation of wildlife habitat, earning LEED points, increasing marketability, etc. These benefits are even harder to quantify and less obvious but they do make green roofs a more desirable candidate for green buildings roofing systems.

It was found that among all quantified green roofs' benefits, electricity saving for space cooling accounted for the greatest ROI segments. In this study, the energy saving for cooling in the five-floor Skaggs building was simulated and estimated based on the behavior observed in the 10-floor Athens administrative building, assuming that the saving percentage decay performs in the same manner, i.e. with the same decay parameter. However, the Skaggs building will contain more laboratory functions than office functions, requiring greater cooling due to instrument and equipment internal heat load gains. Within the scope of this study, the difference due to functional activities of labs versus office space was not considered to limited data of cooling loads in laboratory buildings. In the future study, if considerable, it is necessary for both field experiments and model simulation to involve the building operation factors.

A 40-year life cycle cost analysis has been performed in this study, for green roof, black roof, and reflective roof alternatives, respectively. Based on the financial analysis, a 50\% coverage extensive green roof, by Hydrotech ${ }^{\circledR}$ Garden Roof Assembly or similar system, is recommended for the Skaggs Pharmacy Institute building. Financially, the implementation will cost around $\$ 300,000$ and has a breakeven point of 27 years. The shorter breakeven, positive NPV, and 100\% ROI make the green 


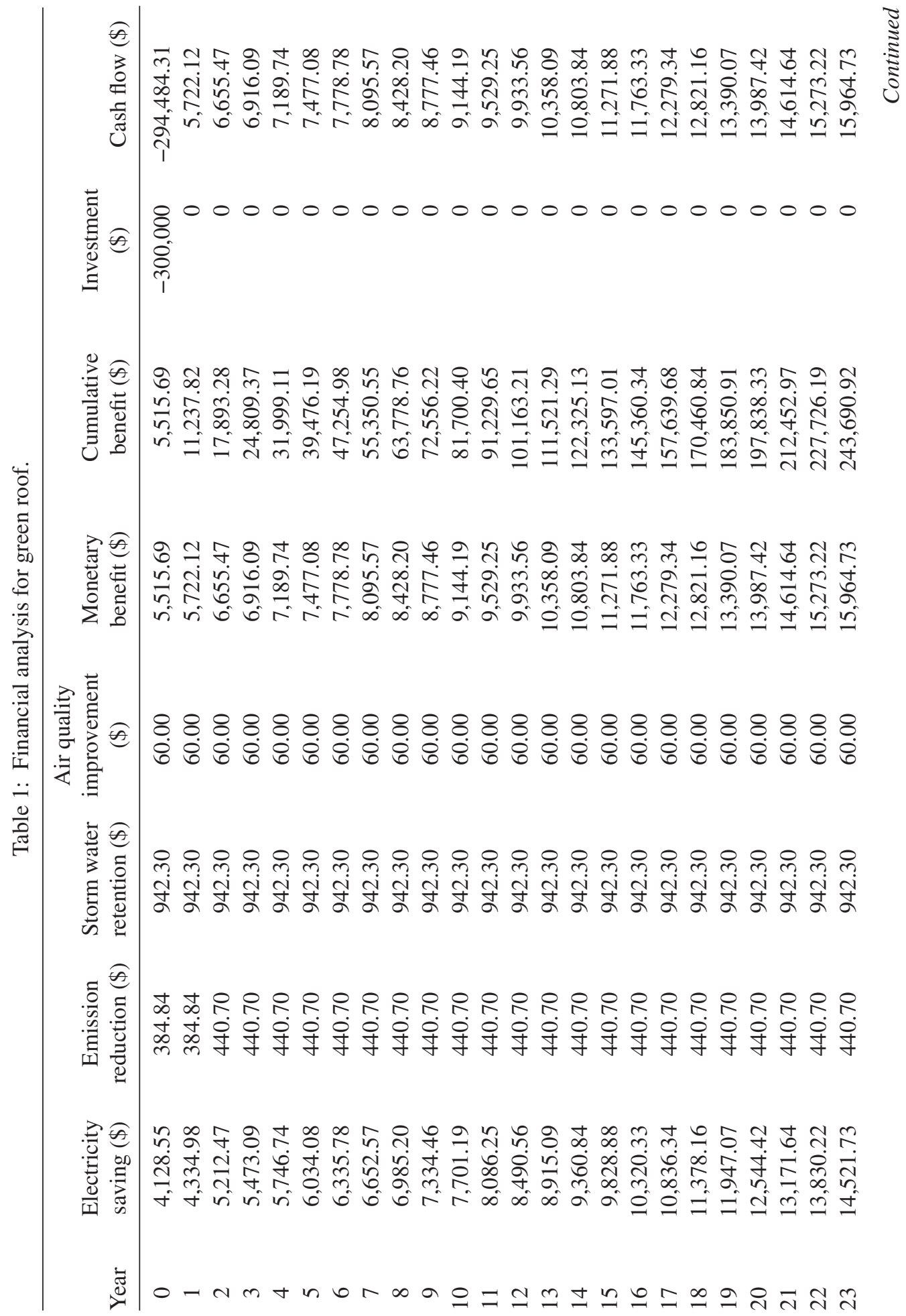




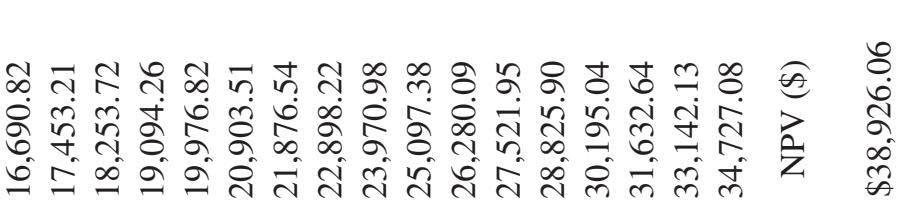

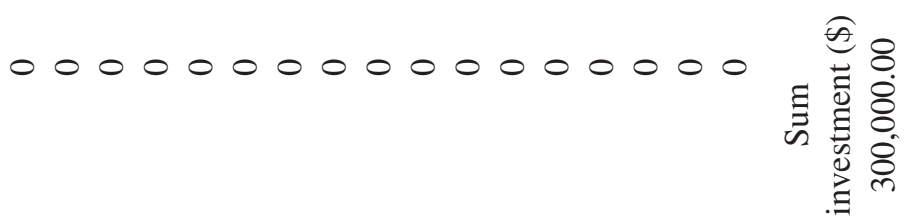

ำ

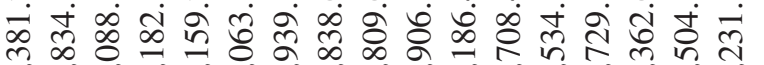

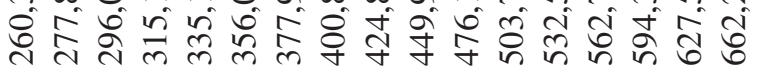

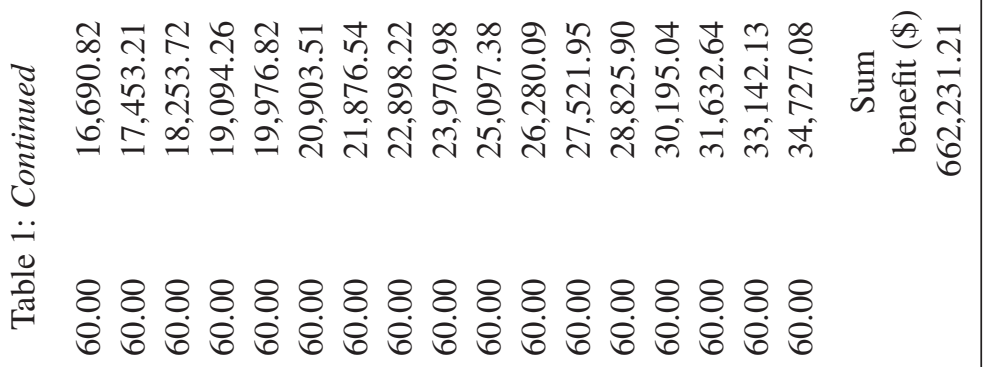

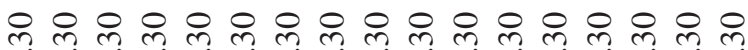

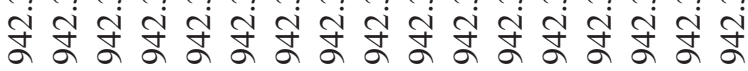

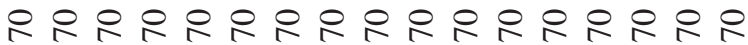

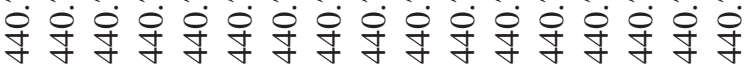

๙ 守家家 ம்

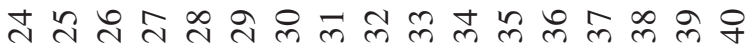


Table 2: Financial analysis for conventional black roof and reflective roof.

\begin{tabular}{|c|c|c|c|c|c|c|}
\hline Year & $\begin{array}{l}\text { Electricity } \\
\text { saving (\$) }\end{array}$ & $\begin{array}{l}\text { Emission } \\
\text { reduction (\$) }\end{array}$ & $\begin{array}{l}\text { Monetary } \\
\text { benefit (\$) }\end{array}$ & $\begin{array}{l}\text { Cumulative } \\
\text { benefit (\$) }\end{array}$ & $\begin{array}{c}\text { Investment } \\
(\$)\end{array}$ & Cash flow $(\$)$ \\
\hline 0 & $1,997.69$ & 186.21 & $2,183.90$ & $2,183.90$ & $-105,000$ & $-102,816.10$ \\
\hline 1 & $2,097.57$ & 186.21 & $2,283.78$ & $4,467.68$ & 0 & $2,283.78$ \\
\hline 2 & $2,202.45$ & 186.21 & $2,388.66$ & $6,856.34$ & 0 & $2,388.66$ \\
\hline 3 & $2,312.57$ & 186.21 & $2,498.78$ & $9,355.12$ & 0 & $2,498.78$ \\
\hline 4 & $2,428.20$ & 186.21 & $2,614.41$ & $11,969.53$ & 0 & $2,614.41$ \\
\hline 5 & $2,549.61$ & 186.21 & $2,735.82$ & $14,705.36$ & 0 & $2,735.82$ \\
\hline 6 & $2,677.09$ & 186.21 & $2,863.30$ & $17,568.66$ & 0 & $2,863.30$ \\
\hline 7 & $2,810.95$ & 186.21 & $2,997.16$ & $20,565.81$ & 0 & $2,997.16$ \\
\hline 8 & $2,951.49$ & 186.21 & $3,137.70$ & $23,703.52$ & 0 & $3,137.70$ \\
\hline 9 & $3,099.07$ & 186.21 & $3,285.28$ & $26,988.80$ & 0 & $3,285.28$ \\
\hline 10 & $3,254.02$ & 186.21 & $3,440.23$ & $30,429.03$ & 0 & $3,440.23$ \\
\hline 11 & $3,416.72$ & 186.21 & $3,602.93$ & $34,031.96$ & 0 & $3,602.93$ \\
\hline 12 & $3,587.56$ & 186.21 & $3,773.77$ & $37,805.73$ & 0 & $3,773.77$ \\
\hline 13 & $3,766.94$ & 186.21 & $3,953.15$ & $41,758.88$ & 0 & $3,953.15$ \\
\hline 14 & $3,955.28$ & 186.21 & $4,141.49$ & $45,900.37$ & 0 & $4,141.49$ \\
\hline 15 & $4,153.05$ & 186.21 & $4,339.26$ & $50,239.63$ & 0 & $4,339.26$ \\
\hline 16 & $4,360.70$ & 186.21 & $4,546.91$ & $54,786.54$ & 0 & $4,546.91$ \\
\hline 17 & $4,578.74$ & 186.21 & $4,764.95$ & $59,551.49$ & 0 & $4,764.95$ \\
\hline 18 & $4,807.67$ & 186.21 & $4,993.88$ & $64,545.37$ & 0 & $4,993.88$ \\
\hline 19 & $5,048.06$ & 186.21 & $5,234.27$ & $69,779.64$ & 0 & $5,234.27$ \\
\hline 20 & $5,300.46$ & 186.21 & $5,486.67$ & $75,266.31$ & 0 & $5,486.67$ \\
\hline 21 & $5,565.48$ & 186.21 & $5,751.69$ & $81,018.00$ & 0 & $5,751.69$ \\
\hline 22 & $5,843.76$ & 186.21 & $6,029.97$ & $87,047.97$ & 0 & $6,029.97$ \\
\hline 23 & $6,135.94$ & 186.21 & $6,322.15$ & $93,370.12$ & 0 & $6,322.15$ \\
\hline 24 & $6,442.74$ & 186.21 & $6,628.95$ & $99,999.07$ & 0 & $6,628.95$ \\
\hline 25 & $6,764.88$ & 186.21 & $6,951.09$ & $106,950.16$ & 0 & $6,951.09$ \\
\hline 26 & $7,103.12$ & 186.21 & $7,289.33$ & $114,239.49$ & 0 & $7,289.33$ \\
\hline 27 & $7,458.28$ & 186.21 & $7,644.49$ & $121,883.98$ & 0 & $7,644.49$ \\
\hline 28 & $7,831.19$ & 186.21 & $8,017.40$ & $129,901.38$ & 0 & $8,017.40$ \\
\hline 29 & $8,222.75$ & 186.21 & $8,408.96$ & $138,310.34$ & 0 & $8,408.96$ \\
\hline 30 & $8,633.89$ & 186.21 & $8,820.10$ & $147,130.44$ & $-126,000$ & $-117,179.90$ \\
\hline 31 & $9,065.58$ & 186.21 & $9,251.79$ & $156,382.24$ & 0 & $9,251.79$ \\
\hline 32 & $9,518.86$ & 186.21 & $9,705.07$ & $166,087.31$ & 0 & $9,705.07$ \\
\hline 33 & $9,994.81$ & 186.21 & $10,181.02$ & $176,268.33$ & 0 & $10,181.02$ \\
\hline 34 & $10,494.55$ & 186.21 & $10,680.76$ & $186,949.08$ & 0 & $10,680.76$ \\
\hline 35 & $11,019.27$ & 186.21 & $11,205.48$ & $198,154.57$ & 0 & $11,205.48$ \\
\hline 36 & $11,570.24$ & 186.21 & $11,756.45$ & $209,911.02$ & 0 & $11,756.45$ \\
\hline 37 & $12,148.75$ & 186.21 & $12,334.96$ & $222,245.98$ & 0 & $12,334.96$ \\
\hline
\end{tabular}


Table 2: Continued

\begin{tabular}{lcccccc}
\hline 38 & $12,756.19$ & 186.21 & $12,942.40$ & $235,188.37$ & 0 & $12,942.40$ \\
39 & $13,394.00$ & 186.21 & $13,580.21$ & $248,768.58$ & 0 & $13,580.21$ \\
40 & $14,063.70$ & 186.21 & $14,249.91$ & $263,018.49$ & 0 & $14,249.91$ \\
& & $\begin{array}{c}\text { Reflective } \\
\text { roof }\end{array}$ & Sum & $\begin{array}{c}\text { Sum } \\
\text { investment }\end{array}$ & NPV $(\$)$ & \\
& & & $(\$)$ & & & \\
& & & $263,018.49$ & $231,000.00$ & Black roof & $\begin{array}{c}\text { Reflective } \\
\text { roof }\end{array}$ \\
& & ROI & $100 \%$ & $-155,668.44$ & $-25,619.81$ \\
\hline
\end{tabular}

roof alternative a better advisable investment than the other two roof alternatives. In conclusion, installing an extensive green roof on half of the Skaggs Pharmacy Institute rooftop is a wise investment for the University.

\section{ACKNOWLEDGEMENTS}

This work has been technically supported by the Office of Sustainability, University of Utah. Details of the GHG Inventory have been shared by Sofia Melo, an employee in Office of Sustainability, University of Utah, who contributed much of the information to create the inventory.

\section{REFERENCES}

[1] United Nations, Report of the World Commission on Environment and Development, General Assembly Resolution 42/187, December 11, 1987. Retrieved November 14, 2007.

[2] Liu, K. \& Baskaran, B., Thermal performance of green roofs through field evaluation, Proceedings for the First North American Green Roof Infrastructure Conference, Awards and Trade Show, May 29-30, 2003 in Chicago, IL, pp. 1-10.

[3] Getter, K.L. \& Rowe, D.B., The role of extensive green roofs in sustainable development. Hortscience, 41(5), pp. 1276-1285, 2006.

[4] Kula, R. Green roofs and maximizing credits under the LEED: green building system. The Green Roof Infrastructure Monitor, Spring 2005.

[5] MacKenna, E., Green Roofs: Energy Saving and Much More, http://hubpages.com/hub/Green_ Roofs_Energy_Savings.

[6] http://www.mnec.gr/el/press_office/DeltiaTypou/articles/article0933.html.

[7] http://oikosteges.gr/index.php/greenroofs/research.

[8] Liu, K.K.Y., Energy efficiency and environmental benefits of rooftop gardens. Construction Canada, 44(2), pp. 17, 20-23, 2002.

[9] Sonne, J. \& Parker, D., Energy performance aspects of a Florida green roof. Sixteenth Symposium on Improving Building Systems in Hot and Humid Climates, December 15-17, 2008 , in Dallas, TX.

[10] Wong, N.H., et al., The effects of rooftop garden on energy consumption of a commercial building in Singapore. Energy and Buildings, 35: pp. 353-364, 2003. doi:10.1016/S0378-7788(02)00108-1

[11] http://en.wikipedia.org/wiki/Salt_Lake_City, and http://en.wikipedia.org/wiki/Athens. 
[12] Campus-wide 2004-2008 energy expenditure record from Jay Sisam, Energy Manager, and private communication with James Steed, utility analyst, Dept. of Energy Management, Facility Management, Univ. of Utah.

[13] Commercial Buildings Energy Consumption Survey (CBECS), available at http://www.eia. doe.gov/emeu/cbecs/cbecs2003/detailed_tables_2003/2003set19/2003pdf/e06.pdf.

[14] Energy Information Administration, Average Retail Price of Electricity to Ultimate Customers by End-Use Sector, by State, available at http://www.eia.doe.gov/cneaf/electricity/epm/ table5_6_a.html.

[15] Private communication with Chris Kanoff, the project manager from Rocky Mountain Power.

[16] Clean energy resources eGRID database, available at http://www.epa.gov/cleanenergy/energyresources/egrid/index.html.

[17] USDA Forest Service, Pacific Southwest Station, Tree Guide, Benefits, Costs, and Strategic Planning, 2007.

[18] Liptan, Planning, zoning and financial incentives for ecoroofs in Portland, Oregon. Proceedings from Greening Rooftops for Sustainable Communities, First North American Green Roof Infrastructure Conference, May 29-30, 2003 in Chicago, IL.

[19] Moran, A., et al., A North Carolina field study to evaluate greenroof runoff quantity, runoff quality, and plant growth. World Water and Environmental Resources Congress and Related Symposia Proceedings of World Water and Environmental Resources Congress 2003.

[20] Simmons, M.T., Gardiner, B., Windhager, S. \& Tinsley, J., Green roofs are not created equal: the hydrologic and thermal performance of six different extensive green roofs and reflective and non-reflective roofs in a sub-tropical climate. Urban Ecosystems, 11, pp. 339-348, 2008. doi:10.1007/s11252-008-0069-4

[21] http://en.wikipedia.org/wiki/Climate_of_Salt_Lake_City.

[22] http://www.hydrotechusa.com/stormwater.htm.

[23] Garden Roof Hydrology, Salt Lake City Example, Sep. 28, 2009, via communication with Greg Sprinkel, Hydrotech representative in Utah.

[24] Salt Lake City Storm Water Ordinance, Chapter 17.75 Storm Water Sewer System, available at http://www.slcgov.com/Utilities/stormwaterordinance.htm.

[25] McPherson, G., USDA Center for Urban Forest Research, Utah Green Annual Conference, January 28, 2008 in Sandy, Utah.

[26] Yang, J., et al., Quantifying air pollution removal by green roofs in Chicago. Atmospheric Environment, 42, pp. 7266-7273, 2008. doi:10.1016/j.atmosenv.2008.07.003

[27] Currie, B.A. \& Bass, B., Estimates of air pollution mitigation with green plants and green roofs using the UFORE model. Urban Ecosystem, 11, pp. 409-422, 2008. doi:10.1007/s11252-008-0054-y

[28] Deutsch, B., et al., Re-greening Washington, DC: A Green Roof Vision Based on Quantifying Storm Water and Air Quality Benefits, 2005.

[29] Nowak, D.J., et al., Understanding and Quantifying Urban Forest Structure, Functions, and Value. USDA Forest Service, 2002.

[30] Private communication with Carpenter Shop and Roofing Department. Facility Management, University of Utah.

[31] Roofing price estimation calculator, available at http://www.coolflatroof.com/roofing-pricecalculator.php.

[32] Konopacki, S. \& Akbari, H., Measured Energy Savings and Demand Reduction from a Reflective Roof Membrane on a Large Retail Store in Austin, Lawrence Berkeley National Laboratory Report LBNL-47149, Berkeley, CA 2001. 
[33] Konopacki, S. \& Akbari, H., Energy Savings for Heat Island Reduction Strategies in Chicago and Houston (Including Updates for Baton Rouge, Sacramento, and Salt Lake City, LBNL49638, Berkeley, CA 2002.

[34] Discount Rates for Cost-Effectiveness, Lease-Purchase, and Related Analyses for OMB Circular No. A-94. Available at http://www.whitehouse.gov/omb/rewrite/circulars/a094/a94_ appx-c.html. 